\title{
IMPROVING THE QUALITY OF ORNAMENTAL BULBOUS WITH PLANT GROWTH-PROMOTING RHIZOBACTERIA (PGPR)
}

\author{
Domenico Prisa $^{1}$, Alessandra Benati ${ }^{2}$ \\ ${ }^{1}$ CREA Research Centre for Vegetable and Ornamental Crops, Council for Agricultural Research \\ and Economics, Via dei Fiori 8, 51012 Pescia, PT, Italy \\ ${ }^{2}$ Associazione P.A.C.M.E. Le Tribù della Terra ONG
}

${ }^{1}$ Corresponding author: Domenico Prisa

Article DOI: https://doi.org/10.36713/epra7029

DOI No: $10.36713 /$ epra7029

\begin{abstract}
The aim of this work was to use Plant growth promoting rhizobacteria (PGPR) for the improvement of cultivation and agronomic and pathogen protection characteristics of ornamental bulbous plants such as Tulip (fam. Liliacee), Iris (fam. Iridacee), Freesia (fam. Iridacee) and Narcissus (fam. Amarillidacee). The experiments, started in November 2020, were conducted in the greenhouses of CREA-OF in Pescia (Pt), Tuscany, Italy. The experimental groups were: i) group control irrigated with water and substrate previously fertilized; ii) group with Effective microorganisms irrigated with water and substrate previously fertilized; iii) group with beneficial bacteria (TNC Bactorr ${ }^{\text {s13 }}$ ) irrigated with water and substrate previously fertilized; iv) group with beneficial bacteria (Tarantula powder Advanced nutrients) irrigated with water and substrate previously fertilized. The trial showed a significant improvement in the agronomic parameters analysed on plants obtained from Narcissus, Iris, Tulip and Freesia bulbs treated with microorganisms. In particular, there was an increase in plant height, vegetative and root weight, bulb weight and diameter, and flower duration. In addition, the use of microorganisms in the growing medium showed a significant increase in the biocontrol of Botrytis cinerea. The treatment with Effective microorganisms (EM) showed the most significant results for all agronomic parameters analysed. The improvement in plant growth brought about by the activity of bacteria is a key aspect of achieving sustainable agricultural goals in the future. More research is needed in this field to identify new soil microbial strains that can be used for the formulation of new products applicable for improving the quality and resistance to biotic and abiotic stresses of potted plants.
\end{abstract}

KEY-WORDS: Ornamental bulbs; Microorganisms; Sustainable agriculture; Flowers; Pot plants

\section{INTRODUCTION}

\section{The Bulbous Plants}

The history of the introduction of bulbous plants into cultivation is long and adventurous. The saffron crocus (Crocus sativus) was already cultivated 4000 years ago in Crete, where the edible, healing and dyeing stigmas of this small autumn flower were the focus of a flourishing international trade. Half a millennium later, Pharaoh Tutmosi III launched the fashion of perfuming linen and people with powdered Iris rhizomes - a successful idea that has survived to this day. Two thousand years ago, among the early Christians, the white-flowered St Anthony's lily (Lilium candidum), which the Romans had introduced from Asia Minor, became the symbol of the Virgin Mary and purity [1]. On the other side of the world, more than a thousand years ago the
Aztecs cultivated Tigridia pavonia as a tribute to the gods. This species grows wild in Peru and Brazil and has large, almost triangular flowers, coloured red, pink, yellow or white, with a hollow centre like a small cup, white and darkly speckled. In Europe, however, until the Renaissance the choice of flowering bulbous plants was far from vast; ladies could grow clumps of fragrant lilies of the valley, blue Florentine irises and little more, or what the local wild flora had to offer. Traditionally, the beginning of a new course dates back to 1554 . Bulbous plants are inexpensive, easy to grow and with such a choice that they tempt anyone to become a collector [1].

\section{Main Bulbous Families}

The lily (Liliaceae), amaryllis (Amarillidaceae) and iris (Iridaceae) families 
compete for first place in terms of the number of species offered to the garden cause. Among the most popular bulbous plants, tulips, hyacinths, muscari, fritillaries, scillaria and lilies of the valley are spring lilies, while Agapanthus, Allium and Eremurus brighten up summer beds. Snowdrops, narcissus, bellflowers and clivia are amaryllis-like plants, while the very early crocus, freesia and gladiolus belong to the iridaceae, as well as irises of course.

The Araceae (Arum, Caladium, Zantedeschia) and Ranuncolaceae (Anemone, Ranunculus, Eranthis) families make a significant contribution to bulb gardens. Other families offer a single genus, such as Begoniaceae (Begonia), Oxalidaceae (Oxalis), Cannaceae (Canna) and Alstroemeriaceae (Altroemeria).

Some families are surprising because there are very few species that originate from a bulb or other enlarged underground organ. This is the case, for example, with the Primulaceae, which contribute cyclamens (Cyclamen), and the Asteraceae, the endless daisy family, represented by the genus Dahlia. Finally, the aristocratic Orchidaceae family, one of the most evolved in the plant kingdom, also contributes with some terrestrial species with underground pseudobulbs (Bletilla, Pleione) [2].

\section{Plant-Microorganisms Interaction}

Plants have the ability to influence soil bacterial communities by producing root exudates specific to the plant species grown. Microorganisms are able to use these substances for their multiplication and are crucial for plant biology by producing substances with a similar action to plant hormones that induce cell differentiation, root development and changes in root hair growth. Root colonization by microorganisms can initiate a symbiosis as the beginning of a disease [3].

The micro-organisms in the rhizosphere are decisive in the growth and defence of plants.
Rhizobacteria can be classified into extracellular (ePGPR) organisms that live mainly in the rhizosphere and intracellular (iPGPR) organisms that colonize the internal structures of the root. Several Plant Growth Promoting Rhizobacteria can be present in the soil, the most important of which include Nitrotobacter, Bacillus, Pseudomonas, Azospirillum, Agrobacterium, Burkholderia, Bradyrhizobium, Rhizobium, Frankia, Erwinia, Flavobacterium, Chromobacterium, Caulobacter, Arthrobacter, Allorhizobium, Mesorhizobium [4]. They have the capacity to improve the characteristics and fertility of the soil, thus favouring the cultivation of plants. The colonization of the roots takes place through various mechanisms such as the formation of siderophores, the solubilization of mineral phosphates and potassium, nitrogen fixation, and the production of phytophorons. In order to improve the quality of crops it is certainly necessary today to use microbial inoculants able to promote plant growth, control diseases and stimulate soil fertility [5].

In order to improve the quality and quantity of agricultural production without adversely affecting the biodiversity of the agro-system, there is an increasing need to use microbial inoculants that promote plant growth, disease control agents and soil health enhancers. PGPRs also play an important role in improving plant health, resistance to environmental stress, and soil bioremediation [6]; [7].

The aim of this work was to use Plant growth promoting rhizobacteria (PGPR) for the improvement of cultivation and agronomic and pathogen protection characteristics of ornamental bulbous plants such as tulip (fam. Liliacee), Iris (fam. Iridacee), freesia (fam. Iridacee) and narcissus (fam. Amarillidacee) (Figure 1).
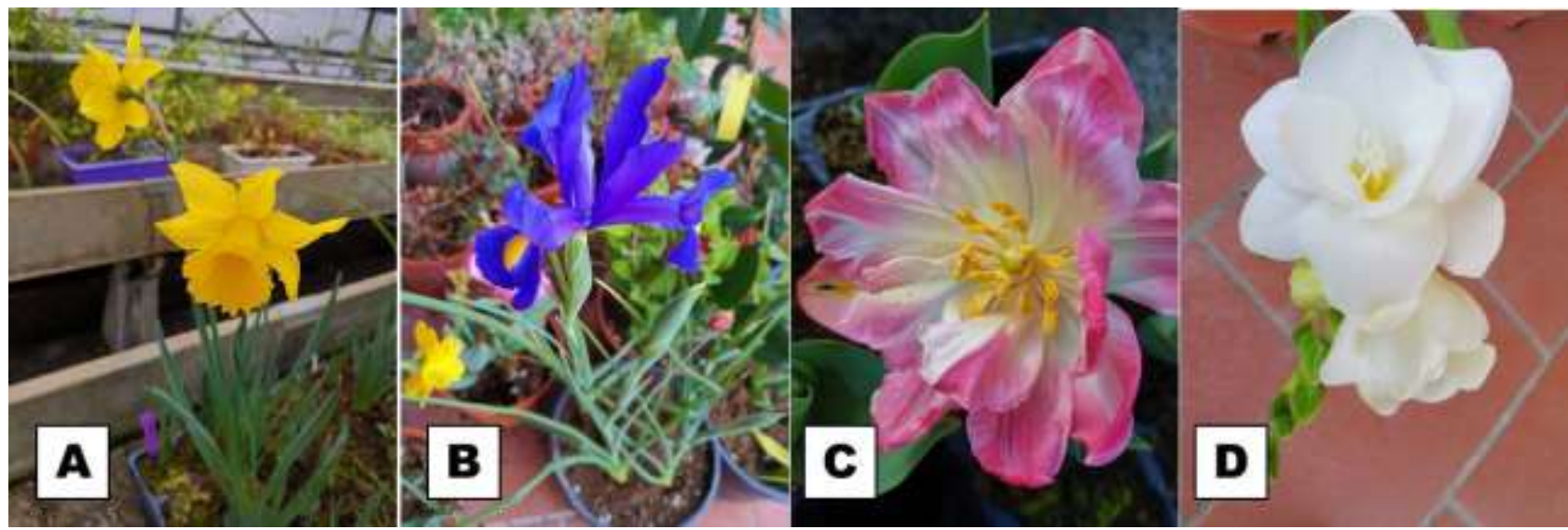

Figure 1 - Particulars of Narcissus (A), Iris (B), Tulip (C) and Freesia (D) flowers 


\section{MATERIAL AND METHODS}

The experiments, started in November 2020, were conducted in the greenhouses of CREA-OF in Pescia (Pt), Tuscany, Italy $\left(43^{\circ} 54^{\prime} \mathrm{N} 10^{\circ} 41^{\prime} \mathrm{E}\right)$ on Narcissus, Iris, Tulip and Freesia bulbs. The plants were placed in plateau with 54 holes; 162 bulbs per thesis, divided into 3 replicas of 54 plants each. All plants were fertilized with a controlled release fertilizer $\left(3 \mathrm{~kg} \mathrm{~m}^{-3}\right.$ Osmocote Pro ${ }^{\circledR}, 9-12$ months with $190 \mathrm{~g} / \mathrm{kg} \mathrm{N}, 39$ $\mathrm{g} / \mathrm{kg} \mathrm{P}, 83 \mathrm{~g} / \mathrm{kg} \mathrm{K}$ ) mixed with the growing medium before transplanting. The experimental groups were:

- group control (CTRL) (peat 60\% + pumice $40 \%$ ), irrigated with water and substrate previously fertilized;

- group with Effective microorganisms (EM) (peat $60 \%+$ pumice $40 \%$ ) irrigated with water and substrate previously fertilized, dilution 1:100 (1L of EM inoculum dilution 1:100 was used for each 10L of peat) (EM activated with molasses: Lactic acid bacteria - Lactobacillus plantarum, L. casei, Streptoccus lactis, Photosynthetic bacteria Rhodopseudomonas palustrus, Rhodobacter spaeroides; Yeast - Saccharomyces cereviasiae, Candida utilis; Actinomycetes Streptomyces albus, S. griseus; fermenting fungi - Aspergillus oryzae, Mucor hiemalis; EM is a fermented mixed culture of naturally occurring species of microorganisms coexisting in an acid environment $(\mathrm{pH}$ less than 3,5). Micro-organisms in EM improve crop health and yield by increasing photosynthesis, producing bioactive substances such as hormones and enzymes, accelerating the decomposition of organic materials and controlling soil diseases. Effective micro-organisms can be used as herbal insecticides to control insects and pathogenic microorganisms and can also be used as plant growth inducers;

- group with beneficial bacteria (BAC1) (peat $60 \%+$ pumice $40 \%$ ) irrigated with water and substrate previously fertilized, (TNC Bactors $^{13}$ : Bacillus amyloliquefaciens, $B$. brevis, $B$. cirulans, B. coagulans, B. firmus, $B$. halodenitrificans, $B$. laterosporus, $B$. licheniformis, $B$. megaterium, B. mycoides, $B$. pasteuri, $B$. polymyxa, B. Subtilis $\left(1.3 \times 10^{11} \mathrm{cfu} / \mathrm{kg}\right) ;$ Mix $1.5 \mathrm{~g}$ (approx $\left.1 / 2 \mathrm{tsp}\right)$ with every litre of soil;

- group with beneficial bacteria (BAC2) (peat $60 \%+$ pumice $40 \%$ ) irrigated with water and substrate previously fertilized, Tarantula powder Advanced nutrients: A. Globiformis 25,000 cfm/ml, B. Brevis 2,000,000 cfm $/ \mathrm{ml}$, $B$. Coagulans $500,000 \mathrm{cfm} / \mathrm{ml}, \quad B$. Licheniformis $5,000,000 \mathrm{cful} / \mathrm{ml}, \quad B$. Megaterium 500,000 cfu/ml, B. Polymyxa
50,000 cfu/ml, B. Pumilis 50,000 cfu/ml, B. Subtilis 1,000,000 cfu/ml, B. Thuringiensis $100,000 \quad \mathrm{cfu} / \mathrm{ml}, \quad$ B.Thuringiensis Canadiensis 50,000 cfu/ml, P. Polymyxa $300,000 \mathrm{cfu} / \mathrm{ml}$. Mix $2 \mathrm{gr}$ every litre of water.

The plants were watered 2 times a week and grown for 6 months. The plants were irrigated with drip irrigation. The irrigation was activated by a timer whose program was adjusted weekly according to climatic conditions and the fraction of leaching. On April 20, 2021, plant height, vegetative weight, roots weight, bulbs weight and diameter, flowers duration, were analysed. In addition, the mortality of bulbs caused by Botrytis cinerea was evaluated.

\section{Statistical Analysis}

The experiment was carried out in a randomized complete block design. Collected data were analysed by one-way ANOVA, using GLM univariate procedure, to assess significant $(P \leq 0.05$, 0.01 and 0.001$)$ differences among treatments. Mean values were then separated by LSD multiple-range test $(P=0.05)$. Statistics and graphics were supported by the programs Costat (version 6.451) and Excel (Office 2010).

\section{RESULTS AND DISCUSSION}

The trial showed a significant improvement in the agronomic parameters analysed on plants obtained from Narcissus, Iris, Tulip and Freesia bulbs treated with microorganisms. In particular, there was an increase in plant height, vegetative and root weight, bulb weight and diameter, and flower duration. In addition, the use of microorganisms in the growing medium showed a significant increase in the biocontrol of Botrytis cinerea. The treatment with Effective microorganisms (EM) showed the most significant results for all agronomic parameters analysed.

In (Table 1), in Narcissus there was a significant increase in plant height in (EM) with $35.78 \mathrm{~cm}$ compared to $35.00 \mathrm{~cm}$ in (BAC2), 34.04 $\mathrm{cm}$ in (BAC1) and $32.10 \mathrm{~cm}$ in (CTRL). Regarding vegetative weight, thesis (EM) was the best with $30.51 \mathrm{~g}$, followed by (BAC2) with $26.07 \mathrm{~g}$, (BAC1) $25.95 \mathrm{~g}$ and (CTRL50) with $25.37 \mathrm{~g}$ (Figure 2). The same trend for root weight where (EM) showed a weight of $25.11 \mathrm{~g}$, (BAC1) $24.64 \mathrm{~g}$, (BAC2) $24.03 \mathrm{~g}$ and (CTRL) $21.53 \mathrm{~g}$. In terms of bulb weight, (EM) was the best thesis with $17.12 \mathrm{~g}$, followed by (BAC1) with $14.99 \mathrm{~g}$ and (BAC2) with $14.84 \mathrm{~g}$, finally (CTRL) with $13.77 \mathrm{~g}$. In terms of bulb diameter, (EM) was also the best performing thesis with 5.60 $\mathrm{cm}$, compared to $(\mathrm{BAC} 1)$ and $(\mathrm{BAC} 2)$ with $4.40 \mathrm{~cm}$ and (CTRL) with $4.40 \mathrm{~cm}$. The Effective microorganisms (EM) thesis was also the one where flowers lasted the longest with 8 days, compared to 6.20 in (BAC1) and 5.41 in (BAC2) and (CTRL) 
5.22. The (CTRL) thesis was the most affected by Botritys cinerea with 2.80 plants.

In (Table 2), Iris shows a significant increase in plant height in the thesis (EM) with $40.38 \mathrm{~cm}$ followed by (BAC1) with $38.08 \mathrm{~cm}$ and (BAC2) with $37.84 \mathrm{~cm}$, finally the untreated control with 35.86 $\mathrm{cm}$. For vegetative weight, thesis $(\mathrm{EM})$ was the best with $27.75 \mathrm{~g}$, followed by (BAC1) with $24.71 \mathrm{~g}$, (BAC2) $24.35 \mathrm{~g}$ and (CTRL) with $22.62 \mathrm{~g}$. Also for root weight the (EM) showed a weight of $27.59 \mathrm{~g}$, (BAC1) $26.27 \mathrm{~g}$, (BAC2) $25.76 \mathrm{~g}$ and (CTRL) 23.20 g. Concerning bulb weight, (EM) was the best thesis with $18.21 \mathrm{~g}$, succeeded by (BAC1) with $16.29 \mathrm{~g}$ and (BAC2) with $16.35 \mathrm{~g}$, finally (CTRL) with $15.35 \mathrm{~g}$. Also in terms of bulb diameter (EM) was the best thesis with $4.81 \mathrm{~cm}$, compared to $4.00 \mathrm{~cm}$ of (BAC1) and (BAC2) and (CTRL) with $3.83 \mathrm{~cm}$. The thesis with (EM) was also the one where flowers lasted the longest with 12.02 days, compared to 11.10 in (BAC1) and 9.83 (BAC2) and (CTRL) 8.42. The (CTRL) thesis on Iris was also the most affected by Botritys cinerea with 1.28 plants.

In (Table 3), in Tulip, significant plant height of the thesis (EM) with $28.78 \mathrm{~cm}$ is noted followed by (BAC1) with $27.31 \mathrm{~cm}$ and $(\mathrm{BAC} 2)$ with 26.52 $\mathrm{cm}$, finally the untreated control with $25.94 \mathrm{~cm}$. For vegetative weight, thesis (EM) was the best with $36.58 \mathrm{~g}$, followed by (BAC2) with $33.96 \mathrm{~g}$, (BAC1) $32.10 \mathrm{~g}$ and (CTRL) with $31.13 \mathrm{~g}$. In roots, all the theses treated with microorganisms showed a significant increase in weight compared to the control (Figure 3). For bulb weight, (EM) was the best thesis with $38.25 \mathrm{~g}$, followed by (BAC1) with $35.71 \mathrm{~g}$ and (BAC2) with $35.27 \mathrm{~g}$, and finally (CTRL) with 32.93 g. For bulb diameter, (EM) was the best thesis with $7.21 \mathrm{~cm}$, compared to $6.04 \mathrm{~cm}$ of (BAC2), $5.83 \mathrm{~cm}$ $(\mathrm{BAC} 1)$ and $5.66 \mathrm{~cm}(\mathrm{CTRL})$. The thesis with (EM) was also the one where flowers lasted the longest with 10.81 days, compared to 8.64 in (BAC2) and 5.83 in (BAC1) and (CTRL) 6.83. Thesis (CTRL) also on Tulip was the one most affected by Botritys cinerea with 2.00 plants.

In (Table 4), in Freesia the effect of Effective microorganisms on plant height is evident with 35.71 $\mathrm{cm}$ followed by (BAC2) with $34.71 \mathrm{~cm}$ and (BAC2) with $34.34 \mathrm{~cm}$, finally the untreated control with $30.96 \mathrm{~cm}$. For vegetative and root weight, thesis (EM) was the best with $27.66 \mathrm{~cm}$ and $25.89 \mathrm{~cm}$ respectively (Figure 4). Moreover, a significant improvement in bulb weight is shown in (EM) with $16.36 \mathrm{~g}$, compared to $15.47 \mathrm{~g}$ of (BAC1) and $14.84 \mathrm{~g}$
(BAC2) and $14.54 \mathrm{~g}$ of (CTRL) (Figure 5). There were no significant differences between the various theses with regard to flowering time, while again the control thesis was the worst with regard to Botritys cinerea attack.

Microbial inoculants are generally products that contain microorganisms, usually selected from plant roots and root zones. Research shows that they can improve plant growth by up to $40 \%$ by colonising the rhizosphere or plant roots, promoting seed germination or plant development. It is evident how microorganisms can improve soil fertility and crop production by solubilising soil nutrients and making them more available to the roots [8]. In addition, due to their ability to biocontrol, they can protect plants from pests and diseases. Plant growth promoting rhizobacteria (PGPR), for example, can improve root development, prolong plant and flower life, degrade harmful substances, and increase the resistance of young plants to biotic and abiotic stresses [9]; [10]. Another interesting aspect is that normally the use of microbial inoculants can be reduced over the years, because they slowly colonise surfaces and are able to multiply independently. Some micro-organisms commonly used as biofertilizers can fix atmospheric nitrogen and solubilise phosphate. Many phytohormones are produced as a result of the stimulation of bacteria on plants and are used as biofertilizers [11].

They can provide the plant with growthenhancing substances such as indol acetic acid (IAA), amino acids and vitamins, leading to improved productivity, soil fertility and increased crop yields [12]. In this trial, it was evident how the use of microorganisms colonizing the rhizosphere, in particular Effective microorganisms (EM), succeeded in improving the productive quality of bulb plants, increasing vegetative and root parameters, flowers life and defence against pathogens like Botritys cinerea. Aspects and results also recurred in other experiments [13]; [14]; [15], but not too frequently on ornamental bulb plants. The use of biofertilizers can be useful in improving crop yields, as microorganisms can convert the insoluble form of nutrients to the soluble form, improving soil characteristics and facilitating plant growth [16]. Biofertilizers are an alternative to chemical fertilizers, as they contain natural components that do not harm plants. They can protect crops from disease development, fungal attack and protect the plant from other diseases, fungal attack and free pollutants [17]. 
EPRA International Journal of Multidisciplinary Research (IJMR) - Peer Reviewed Journal Volume: 7 | Issue: 5 | May 2021|| Journal DOI: 10.36713/epra2013 || SJIF Impact Factor 2021: 8.047 || ISI Value: 1.188

Table 1 - Evaluation of PGPR on agronomic characters and pathogen protection on Narcissus

\begin{tabular}{|c|c|c|c|c|c|c|c|}
\hline Groups & $\begin{array}{l}\text { Plant } \\
\text { height } \\
\text { (cm) }\end{array}$ & $\begin{array}{c}\text { Vegetative } \\
\text { weight } \\
\text { (g) }\end{array}$ & $\begin{array}{c}\text { Roots } \\
\text { weight } \\
\text { (g) }\end{array}$ & $\begin{array}{c}\text { Bulb } \\
\text { weight } \\
\text { (g) }\end{array}$ & $\begin{array}{c}\text { Bulb } \\
\text { diameter } \\
\text { (cm) }\end{array}$ & $\begin{array}{c}\text { Flowers } \\
\text { duration } \\
\text { (days) }\end{array}$ & $\begin{array}{c}\text { Plants affected } \\
\text { by Botrytis } \\
\text { cinerea } \\
\left(\mathbf{n}^{\circ}\right)\end{array}$ \\
\hline \multirow{2}{*}{ CTRL } & $32,10 \mathrm{c}$ & $25,37 \mathrm{~b}$ & $21,53 \mathrm{c}$ & $13,77 \mathrm{c}$ & $4,20 \mathrm{~b}$ & $5,22 \mathrm{c}$ & $2,80 \mathrm{a}$ \\
\hline & $35,78 \mathrm{a}$ & $30,51 \mathrm{a}$ & $25,11 \mathrm{a}$ & $17,12 \mathrm{a}$ & $5,60 \mathrm{a}$ & $8,00 \mathrm{a}$ & $0,00 \mathrm{~b}$ \\
\hline EM & $34,04 \mathrm{~b}$ & $25,95 \mathrm{~b}$ & $24,64 \mathrm{ab}$ & $14,99 \mathrm{~b}$ & $4,40 \mathrm{~b}$ & $6,20 \mathrm{~b}$ & $0,41 \mathrm{~b}$ \\
\hline BAC1 & & $26,07 \mathrm{~b}$ & $24,03 \mathrm{~b}$ & $14,84 \mathrm{~b}$ & $4,40 \mathrm{~b}$ & $5,41 \mathrm{c}$ & $0,23 \mathrm{~b}$ \\
\hline BAC2 & $\begin{array}{l}35,00 \\
a b\end{array}$ & & & & & & \\
\hline ANOVA & *** & $* * *$ & *** & *** & $* *$ & $* * *$ & $* * *$ \\
\hline
\end{tabular}

One-way ANOVA; n.s. - non significant; ***,*** significant at $\mathrm{P} \leq 0.05,0.01$ and 0.001 , respectively; different letters for the same element indicate significant differences according to Tukey's (HSD) multiple-range test $(\mathrm{P}=0.05)$.Legend: $(\mathrm{CTRL})$ : control; (EM): Effective microorganisms; (BAC1): TNC Bactorrs13; (BAC2): Tarantula powder Advanced nutrients

Table 2 - Evaluation of PGPR on agronomic characters and pathogen protection on Iris

\begin{tabular}{cccccccc}
\hline Groups & $\begin{array}{c}\text { Plant } \\
\text { height } \\
\text { (cm) }\end{array}$ & $\begin{array}{c}\text { Vegetative } \\
\text { weight } \\
\text { (g) }\end{array}$ & $\begin{array}{c}\text { Roots } \\
\text { weight } \\
\text { (g) }\end{array}$ & $\begin{array}{c}\text { Bulb } \\
\text { weight } \\
\text { (g) }\end{array}$ & $\begin{array}{c}\text { Bulb } \\
\text { diameter } \\
\text { (cm) }\end{array}$ & $\begin{array}{c}\text { Flowers } \\
\text { duration } \\
\text { (days) }\end{array}$ & $\begin{array}{c}\text { Plants affected } \\
\text { by Botrytis } \\
\text { cinerea } \\
\text { (n) }\end{array}$ \\
\hline CTRL & $35,86 \mathrm{c}$ & $22,62 \mathrm{c}$ & $23,20 \mathrm{c}$ & $15,35 \mathrm{c}$ & $3,83 \mathrm{~b}$ & $8,42 \mathrm{~d}$ & $1,28 \mathrm{a}$ \\
EM & $40,38 \mathrm{a}$ & $27,75 \mathrm{a}$ & $27,59 \mathrm{a}$ & $18,21 \mathrm{a}$ & $4,81 \mathrm{a}$ & $12,02 \mathrm{a}$ & $0,00 \mathrm{~b}$ \\
BAC1 & $38,08 \mathrm{~b}$ & $24,71 \mathrm{~b}$ & $26,27 \mathrm{~b}$ & $16,29 \mathrm{~b}$ & $4,00 \mathrm{~b}$ & $11,10 \mathrm{~b}$ & $0,00 \mathrm{~b}$ \\
BAC2 & $37,84 \mathrm{~b}$ & $24,35 \mathrm{~b}$ & $25,76 \mathrm{~b}$ & $16,35 \mathrm{~b}$ & $4,00 \mathrm{~b}$ & $9,83 \mathrm{c}$ & $0,46 \mathrm{~b}$ \\
\hline $\boldsymbol{A N O V A}$ & $* * *$ & $* * *$ & $* * *$ & $* * *$ & $* * *$ & $* * *$ & $* *$ \\
\hline
\end{tabular}

One-way ANOVA; n.s. - non significant; *,**,*** significant at $\mathrm{P} \leq 0.05,0.01$ and 0.001 , respectively; different letters for the same element indicate significant differences according to Tukey's (HSD) multiple-range test $(\mathrm{P}=0.05)$.Legend: $(\mathrm{CTRL})$ : control; (EM): Effective microorganisms; (BAC1): TNC Bactorrs13; (BAC2): Tarantula powder Advanced nutrients

Table 3 - Evaluation of PGPR on agronomic characters and pathogen protection on Tulip

\begin{tabular}{cccccccc}
\hline Groups & $\begin{array}{c}\text { Plant } \\
\text { height } \\
\text { (cm) }\end{array}$ & $\begin{array}{c}\text { Vegetative } \\
\text { weight } \\
\text { (g) }\end{array}$ & $\begin{array}{c}\text { Roots } \\
\text { weight } \\
\text { (g) }\end{array}$ & $\begin{array}{c}\text { Bulb } \\
\text { weight } \\
\text { (g) }\end{array}$ & $\begin{array}{c}\text { Bulb } \\
\text { diameter } \\
\text { (cm) }\end{array}$ & $\begin{array}{c}\text { Flowers } \\
\text { duration } \\
\text { (days) }\end{array}$ & $\begin{array}{c}\text { Plants affected } \\
\text { by Botrytis } \\
\text { cinerea } \\
\text { (n') }\end{array}$ \\
\hline CTRL & $25,94 \mathrm{c}$ & $31,13 \mathrm{c}$ & $27,62 \mathrm{~b}$ & $32,93 \mathrm{c}$ & $5,66 \mathrm{~b}$ & $6,83 \mathrm{c}$ & $2,00 \mathrm{a}$ \\
EM & $28,78 \mathrm{a}$ & $36,58 \mathrm{a}$ & $33,02 \mathrm{a}$ & $38,25 \mathrm{a}$ & $7,21 \mathrm{a}$ & $10,81 \mathrm{a}$ & $0,20 \mathrm{~b}$ \\
BAC1 & $27,31 \mathrm{~b}$ & $32,10 \mathrm{c}$ & $32,51 \mathrm{a}$ & $35,71 \mathrm{~b}$ & $5,83 \mathrm{~b}$ & $7,62 \mathrm{c}$ & $0,42 \mathrm{~b}$ \\
BAC2 & $26,52 \mathrm{c}$ & $33,96 \mathrm{~b}$ & $31,82 \mathrm{a}$ & $35,27 \mathrm{~b}$ & $6,04 \mathrm{~b}$ & $8,64 \mathrm{~b}$ & $0,44 \mathrm{~b}$ \\
\hline $\boldsymbol{A N O V A}$ & $* * *$ & $* * *$ & $* * *$ & $* * *$ & $* * *$ & $* * *$ & $* *$ \\
\hline
\end{tabular}

One-way ANOVA; n.s. - non significant; ***,*** significant at $\mathrm{P} \leq 0.05,0.01$ and 0.001 , respectively; different letters for the same element indicate significant differences according to Tukey's (HSD) multiple-range test $(\mathrm{P}=0.05)$.Legend: $(\mathrm{CTRL})$ : control; (EM): Effective microorganisms; (BAC1): TNC Bactorrsi3; (BAC2): Tarantula powder Advanced nutrients 
EPRA International Journal of Multidisciplinary Research (IJMR) - Peer Reviewed Journal

Volume: 7 | Issue: 5 | May 2021|| Journal DOI: 10.36713/epra2013 || SJIF Impact Factor 2021: 8.047 || ISI Value: 1.188

Table 4 - Evaluation of PGPR on agronomic characters and pathogen protection on Freesia

\begin{tabular}{cccccccc}
\hline Groups & $\begin{array}{c}\text { Plant } \\
\text { height } \\
\text { (cm) }\end{array}$ & $\begin{array}{c}\text { Vegetative } \\
\text { weight } \\
\text { (g) }\end{array}$ & $\begin{array}{c}\text { Roots } \\
\text { weight } \\
\text { (g) }\end{array}$ & $\begin{array}{c}\text { Bulb } \\
\text { weight } \\
\text { (g) }\end{array}$ & $\begin{array}{c}\text { Bulb } \\
\text { diameter } \\
\text { (cm) }\end{array}$ & $\begin{array}{c}\text { Flowers } \\
\text { duration } \\
\text { (days) }\end{array}$ & $\begin{array}{c}\text { Plants affected } \\
\text { by Botrytis } \\
\text { cinerea } \\
\text { (n) }\end{array}$ \\
\hline CTRL & $30,96 \mathrm{c}$ & $24,96 \mathrm{~b}$ & $22,58 \mathrm{c}$ & $14,54 \mathrm{c}$ & $4,00 \mathrm{a}$ & $5,23 \mathrm{c}$ & $2,00 \mathrm{a}$ \\
EM & $35,71 \mathrm{a}$ & $27,66 \mathrm{a}$ & $25,89 \mathrm{a}$ & $16,36 \mathrm{a}$ & $4,20 \mathrm{a}$ & $7,41 \mathrm{a}$ & $0,00 \mathrm{~b}$ \\
BAC1 & $34,34 \mathrm{~b}$ & $25,07 \mathrm{~b}$ & $24,36 \mathrm{~b}$ & $15,47 \mathrm{~b}$ & $4,20 \mathrm{a}$ & $6,43 \mathrm{~b}$ & $0,63 \mathrm{~b}$ \\
BAC2 & $34,71 \mathrm{~b}$ & $25,00 \mathrm{~b}$ & $24,69 \mathrm{~b}$ & $14,84 \mathrm{c}$ & $4,20 \mathrm{a}$ & $6,62 \mathrm{~b}$ & $0,21 \mathrm{~b}$ \\
\hline $\boldsymbol{A N O V A}$ & $* * *$ & $* * *$ & $* * *$ & $* * *$ & $\mathrm{~ns}$ & $* * *$ & $* *$ \\
\hline
\end{tabular}

One-way ANOVA; n.s. - non significant; ***,*** _ significant at $\mathrm{P} \leq 0.05,0.01$ and 0.001 , respectively; different letters for the same element indicate significant differences according to Tukey's (HSD) multiple-range test $(\mathrm{P}=0.05)$.Legend: $(\mathrm{CTRL})$ : control; (EM): Effective microorganisms; (BAC1): TNC Bactorrsi3; (BAC2): Tarantula powder Advanced nutrients

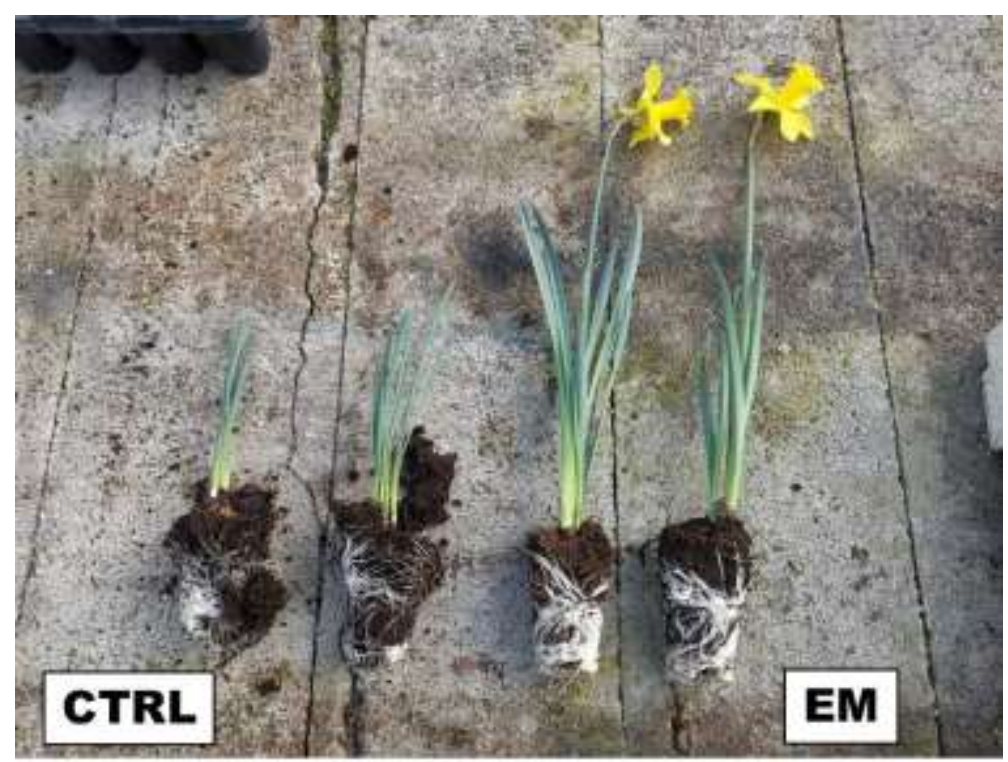

Figure 2 - Comparison between Effective microorganisms (EM) and control on vegetative and roots growth of Narcissus 


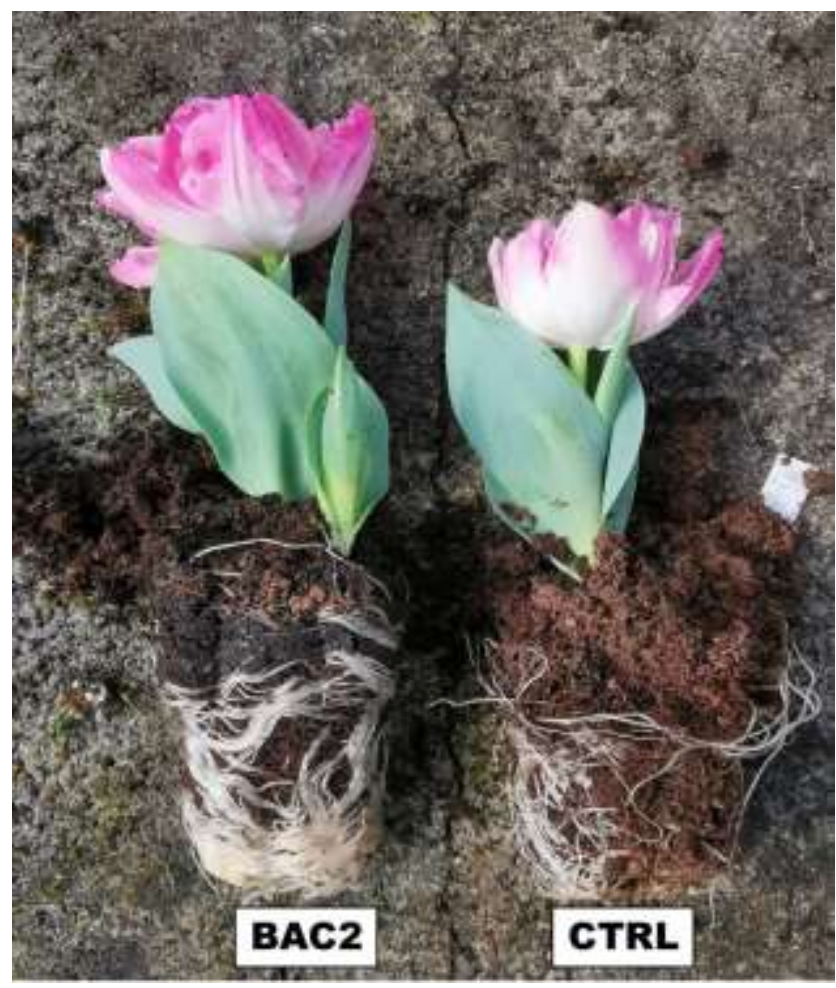

Figure 3 - Effect of beneficial bacteria (BAC2) on roots growth of Tulip
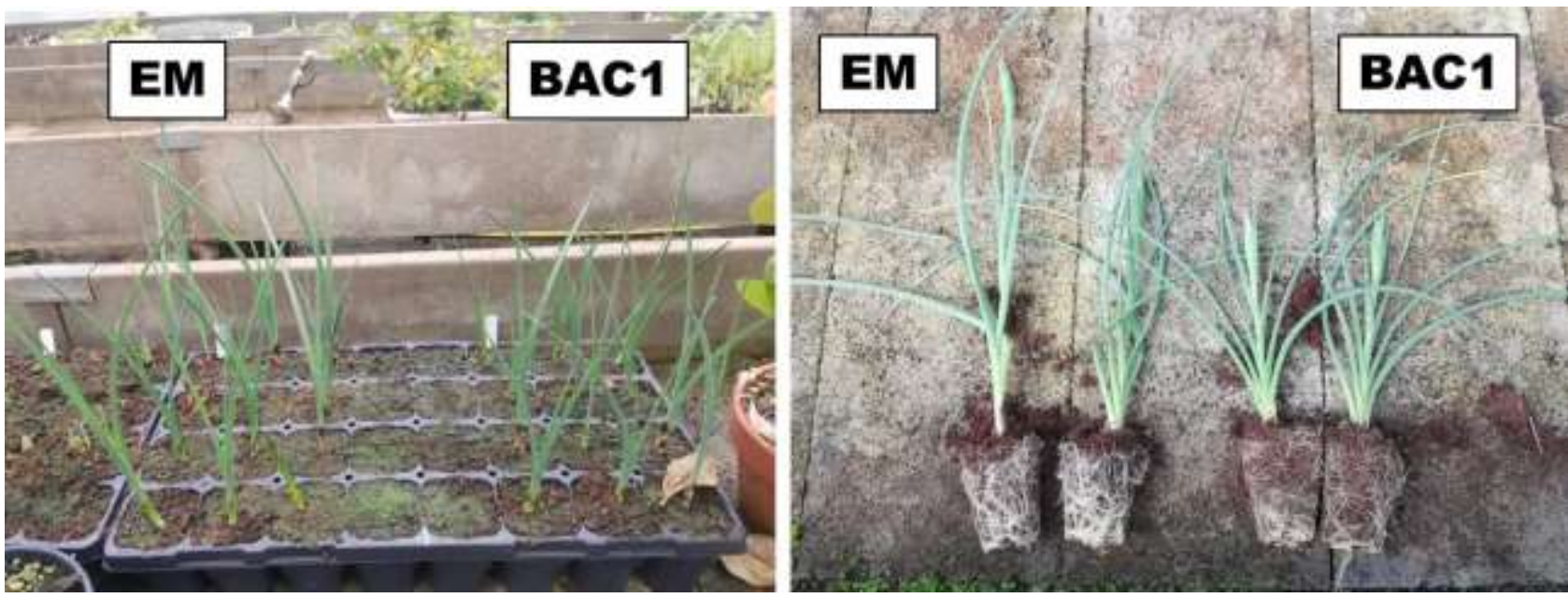

Figure 4 - Comparison between of Effective microorganisms (EM) and beneficial microorganisms (BAC1) on vegetative and roots growth of Freesia 

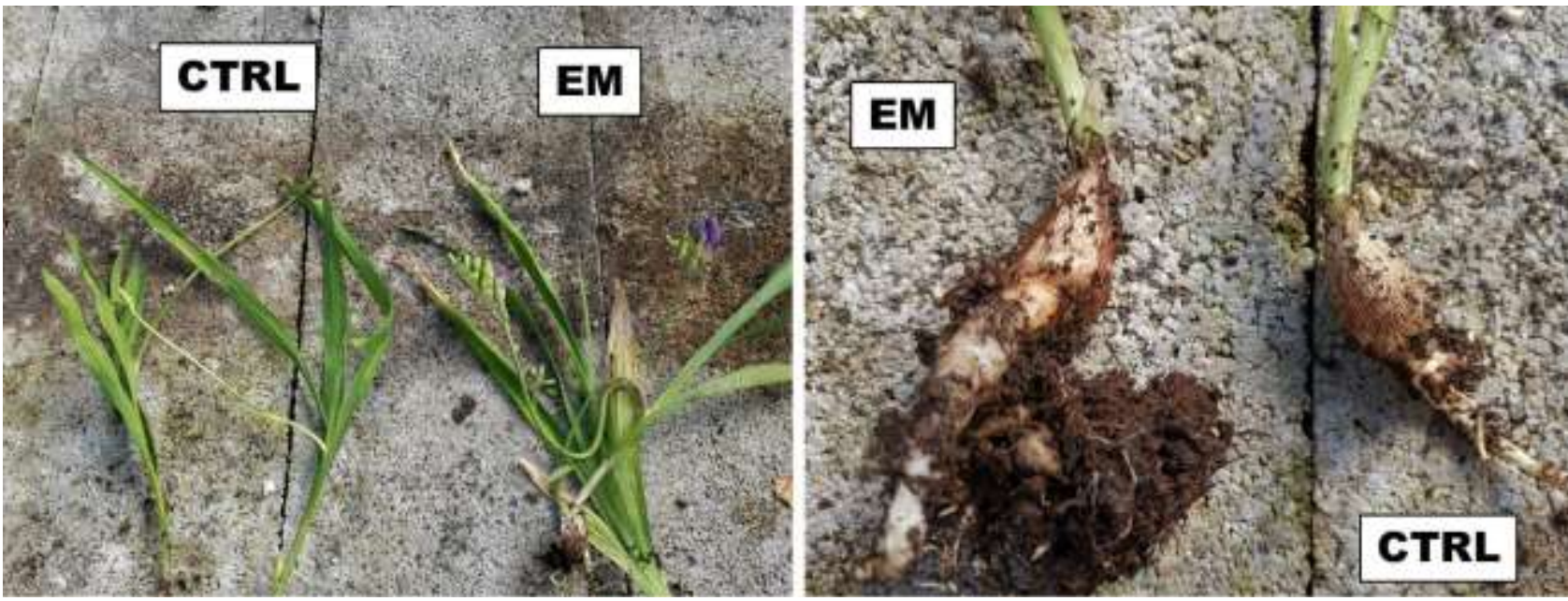

Figure 5 - Effect of Effective microorganisms (EM) on vegetative growth and bulbs diameter of

\section{Freesia}

\section{CONCLUSION}

The physical and chemical properties of the soil, organic matter and phosphorus content influence the presence of bacteria. The improvement in plant growth brought about by the activity of bacteria is a key aspect of achieving sustainable agricultural goals in the future. Microbes are the basis of nutrient cycles in the ecosystem. Knowledge of the composition of the biofertilisers used is essential to exploit the synergistic action of various microbes. Often the microorganisms are strain-specific, so you need to assess whether they are actually functional on the plant you want to cultivate. he development of sustainable farming techniques is driven by the growing demand for microbial-based products. Knowledge of soil characteristics and host specificity of microorganisms is the basis for successful production and application of microbial products. Biofertilizers can maintain crop productivity with a low environmental impact and can be an effective substitute for fertilizers, in particular improving the quality of ornamental flowering species. More research is needed in this field to identify new soil microbial strains that can be used for the formulation of new products applicable for improving the quality and resistance to biotic and abiotic stresses of potted plants.

\section{Acknowledgments}

The research is part of the project "Wander\&Pick: use of ornamental bulbous plants in public areas for artistic and social purposes". Special thanks to Dr.ssa Alessandra Benati for her collaboration in the field experiment.

\section{REFERENCES}

1. The Royal Horticultural Society. Bulbose. (1999). Fabbri editori

2. Pallavicini M., (2009). Bulbose. Varietà, fioritura e cure colturali. Demetra
3. Berg, G., (2009). Plant-microbe interactions promoting plant growth and health: Perspectives for controlled use of microorganisms in agriculture. Appl. Microbiol. Biotechnol. 84:11-18.

4. Thomas, L., Singh, I., (2019). Microbial Biofertilizers: Types and Applications. In Biofertilizers for Sustainable Agriculture and Environment; Springer: Berlin/Heidelberg, Germany, 1-19.

5. Kawalekar, J.S., (2013). Role of biofertilizers and biopesticides for sustainable agriculture. J. Bio. Innov., 2:73-78.

6. Mishra, P., Dash, D., (2014). Rejuvenation of biofertilizer for sustainable agriculture and economic development. Consilience. 41-61.

7. Prisa, D., (2019). Rhizobacteria and zeolites for overcoming saline stress in the cultivation of succulent plants. The International Journal of Engineering and Science 8 (5I):38-41.

8. Mahdi, S.S., Hassan, G., Samoon, S., Rather, H., Dar, S.A., Zehra, B., (2010). Bio-fertilizers in organic agriculture. J. Phytol., 2:42-54.

9. Prisa, D., (2019). Effective microorganisms for germination and root growth in Kalanchoe daigremontiana. World Journal of Advanced Research and Reviews, 3(3):47-53.

10. Prisa, D., (2019). Trichoderma harzianum: biocontrol to Rhizoctonia solani and biostimulation in Pachyphytum oviferum and Crassula falcata. World Journal of Advanced Research and Reviews, 3(3):11-18.

11. Itelima, J., Bang, W., Onyimba, I., Oj, E., (2018). A review: Biofertilizer; a key player in enhancing soil fertility and crop productivity. J. Microbiol. Biotechnol. Rep., 2:22-28.

12. Meena, V.S., Mishra, P.K., Bisht, J.K., Pattanayak, A., (2017). Agriculturally Important Microbes for Sustainable Agriculture: Volume 2: Applications in Crop Production and Protection; Springer: Berlin/Heidelberg.

13. Prisa, D., (2020). Improving Quality of Crocus Sativus Through the Use of Bacillus Subtilis," International Journal of Scientific Research in Multidisciplinary Studies ,6(2):9-15 
14. Prisa, D., (2021). Myrtillocactus geometrizans fruit plant stimulated with Effective microorganisms. Open Access Research Journal of Biology and Pharmacy, 1(1):25-32

15. Prisa, D., (2021). Antifungal and plant growth promoting activity with Bacillus amyloliquefaciens in Aeonium subs. Magna Scientia Advanced Biology and Pharmacy, 1(2):42-50

16. Brahmaprakash, G., Sahu, P.K, (2012). Biofertilizers for sustainability. J. Indian Inst. Sci. 92: 37-62.

17. Sammauria, R., Kumawat, S., Kumawat, P., Singh, J., Jatwa, T.K., (2020). Microbial inoculants: Potential tool for sustainability of agricultural production systems. Arch. Microbiol., 202:677693. 